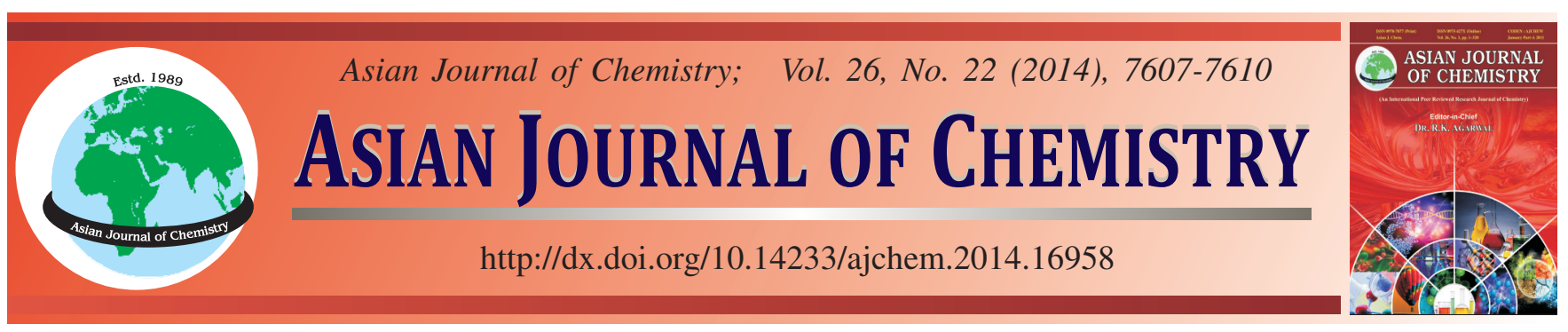

\title{
Determination of Trace Chlortetracycline in Urine Using Phase-Separation Sublation and Ultraviolet Detection
}

\author{
YanMin Hou ${ }^{1, *}$, XiaOJUn ZhaO ${ }^{1}$ and Jimin XIE ${ }^{2}$ \\ ${ }^{1}$ School of Chemistry and Chemical Engineering, Pingdingshan University, Pingdingshan 467000, Henan Province, P.R. China \\ ${ }^{2}$ School of Chemistry and Chemical Engineering, Jiangsu University, Zhenjiang 212013, P.R. China \\ *Corresponding author: E-mail: hympdsu@163.com
}

\begin{abstract}
A novel analytical method is developed for the determination of trace chlortetracycline (CTC) in wastewater by phase-separation sublation coupled with an ultraviolet detector setting at $410 \mathrm{~nm}$. Chlortetracycline can be transformed into tenary complex(Ni-CTC-DNA) in the presence of nickel(II) and deoxyribonucleic acid (DNA), which can be separated by phase-separation sublation easily. The optimum phase-separation sublation was performed on phase-separation reagent using $1 \mathrm{~mol} \mathrm{~L}^{-1}$ sodium chloride, caustic soda solution as acidity regulator and tetrahydrofuran (THF) as solvent. The linear regression equation is $\mathrm{A}=8.33 \times 10^{5} \mathrm{C}-0.0005$, linear range is from $5.1 \times 10^{-8}-1.5$ $\times 10^{-5} \mathrm{~mol} \mathrm{~L}^{-1}$, lower limit of detection (LOD) was $1.82 \times 10^{-9} \mathrm{~mol} \mathrm{~L}^{-1}$. The recoveries of chlortetracycline in water samples were $99.1-101 \%$.
\end{abstract}

Keywords: Chlortetracycline, Phase-separation sublation, Ultraviolet detection.

\section{INTRODUCTION}

Chlortetracycline (CTC) is a broad spectrum antibiotic,it is widely used in livestock and poultry, aquatic animal and plant disease prevention, control and treatment ${ }^{1}$. The residual substance of chlortetracycline which enter into the environment via various channels is toxic and difficult to biodegradation. This is a serious threat for the natural ecological balance system and human health ${ }^{2}$.

The existing literature indicated that the conventional method for determination of chlortetracycline is instrumental analysis method, e.g., spectrophotometric method ${ }^{3}$, high performance liquid chromatography (HPLC) $)^{4-6}$, fluorescence $\operatorname{method}^{7}$, gas chromatography with Tandem mass (GC-MS) ${ }^{8}$ and room temperature phosphorimetry ${ }^{9}$, have usually been developed for the determination of chlortetracycline. The formation of binary complex of chlortetracycline with rare earth elements have already been reported ${ }^{8}$. The above methods are quick and simple, but they require strict analysis medium, the error margin for trace or ultratrace determination of component was heavy. At the same time, the existing literatures showed that the domestic studies focus on food and soil, rarely involved in monitoring of residual tetracyclines complex in water environment.

We looked at the interactivity among chlortetracycline (CTC), Ni(II) and deoxyribonucleic acid (DNA) in this research.
The molecule of chlortetracycline and deoxyribonucleic acid contains a number of donating hydroxyl, carbonyl and amine and competent empty hybrid orbitals in the structure of $\mathrm{Ni}(\mathrm{II})$, They can make up a special tenary complex among the chlortetracycline, $\mathrm{Ni}$ (II) and deoxyribonucleic acid. Thus, we developed a new method for analysis of trace chlortetracycline by phase-separation sublation cooperated with an ultraviolet detector, which is simple and quick.

The technique of phase-separation sublation is a new type of sample pretreatment technology which integrated two-water phase extraction with gas solvent flotation. The basic principle is, first, we should adjust ionic strength of test system with inorganic salt. The inorganic anions and cations ionized form the inorganic salt will combine with a large number of water molecules in the hydration process. The hydrophile organic solvent that relys on hydrogen bonding to water molecules and entering the water system becomes hydrophobically because no free water molecules can be combined, the system is separated quantitatively into the two-phase. Second, under the function of trapping agent, the hydrophobic compounds attached to the bubbles were floated into organic phase because of surface tension. We can get the content of measuring substance by determining the absorbance of organic phase. This technique has the high multiple of enrichment, a large number of treatment sample, using non-toxic or low toxic solvents and easy to automation. It can be used to detect trace compo- 
nent. At the same time, the method will overcome the following shortcomings: A great deal of organic solvent was used, the multiple of enrichment was low (2 to 3 times) in the aqueous two-phase extraction, secondary pollution was befallen in the gas solvent floatation by using toxic organic solvents (benzene, toluene, etc.). This kind of method drew the characteristics with simple equipment, high sensitivity, fast measurement and simple and convenient post-processing. In this paper, this technology conjunction with the spectrophotometric measurement will be used in the detection of chlortetracycline. Schematic diagram of phase-separation sublation was shown in Fig. 1.

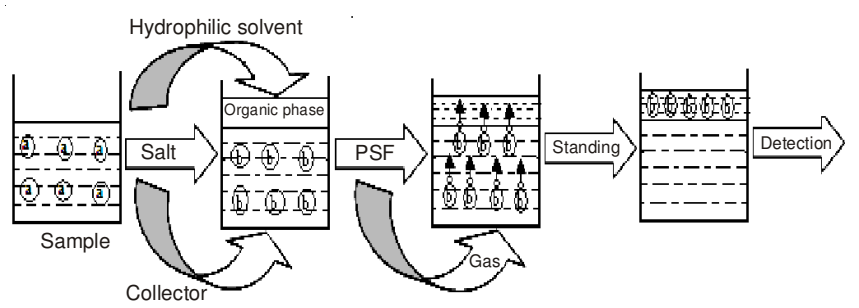

Fig. 1. Principium diagram of phase-separation sublation, (a) chlortetracy-cline; (b) Ni-CTC-DNA; Bubble

\section{EXPERIMENTAL}

All the reagents were of analytical reagent grade. $1 \times 10^{-4}$ mol L $\mathrm{L}^{-1}$ of chlortetracycline (Sinopharm Chemical Reagent Company), $1 \times 10^{-4} \mathrm{~mol} \mathrm{~L}^{-1}$ of a standard Ni(II) solution (preparated with $\mathrm{NiCl}_{2} \cdot 6 \mathrm{H}_{2} \mathrm{O}$, Chinese Zhengzhou pain I Chemical Reagent Factory), $1 \times 10^{-4} \mathrm{~mol} \mathrm{~L}^{-1}$ of deoxyribonucleic acid (Wuhan Huamei Biological Technology Co. Ltd), $\mathrm{Na}_{2} \mathrm{CO}_{3^{-}}$ $\mathrm{NaHCO}_{3}(\mathrm{pH}=10) .0 .01 \mathrm{~mol} \mathrm{~L}^{-1}$ sodium hydroxide, tetrahydrofuran, $\mathrm{HCl}, \mathrm{NaOH}, \mathrm{H}_{2} \mathrm{SO}_{4}$ and other interfering ions solution were obtained from Chinese Chemical company.

UV-265 ultraviolet-obviously spectrophotometer (Shimadzu Corporation); High performance liquid chromatograph (Aglient Technology 1200 series); 722 grating spectrophotometer (Sichuan Ninth Instrument Factory); 320-S acidometer (Meteler-Toledo Instrument Ltd); Electronic analytical balance (Switzerland Meteler Company); phase-separation sublation equipment (self made, shown in Fig. 2).
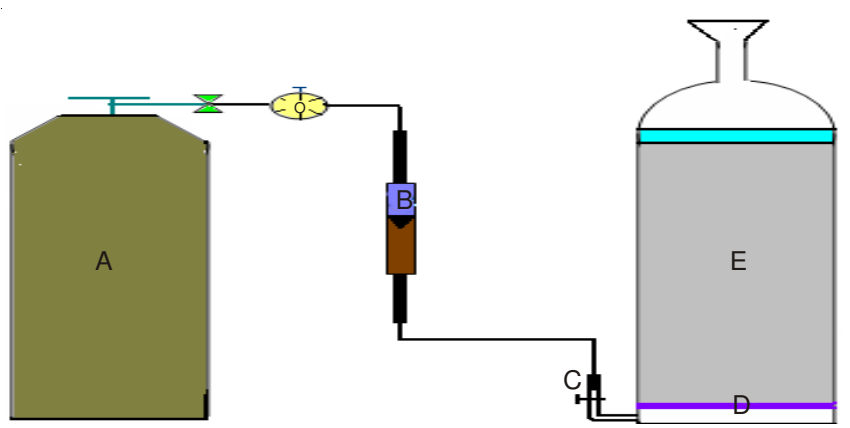

Fig. 2. Apparatus for hydrophilic solvent floatation, (A) Nitrogen cylinder; (B) Rotor flow meter; (C) Impervious glass cock; (D) Glass filter plate; (E) Flotation column

Experimental procedure. $5 \mathrm{~mL}$ of $1 \times 10^{-4} \mathrm{~mol} \mathrm{~L}^{-1}$ chlortetracycline, $6 \mathrm{~mL}$ of $1 \times 10^{-4} \mathrm{~mol} \mathrm{~L}^{-1} \mathrm{Ni}(\mathrm{II}), 5 \mathrm{~mL}$ of $1 \times 10^{-4}$ mol L $\mathrm{L}^{-1}$ deoxyribonucleic acid and $5 \mathrm{~mL}$ of $\mathrm{Na}_{2} \mathrm{CO}_{3}-\mathrm{NaHCO}_{3}$
$(\mathrm{pH}=10)$ buffer solution were added to a $50 \mathrm{~mL}$ beaker. After standing for $5 \mathrm{~min}$, the mixture solution was transferred into the floatation pool and diluted to $200 \mathrm{~mL}$ volume calibration line with $1 \mathrm{~mol} \mathrm{~L}^{-1}$ of $\mathrm{NaCl}, 5 \mathrm{~mL}$ of THF was added. Detection was performed on an ultraviolet detector setting at $410 \mathrm{~nm}$ after phase-separartion sublation in the conditions of $10 \mathrm{~min}$

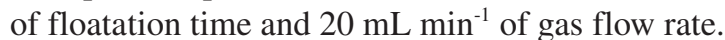

\section{RESULTS AND DISCUSSION}

Absorption spectrum: The spectrum of mixture of chlortetracycline, $\mathrm{Ni}(\mathrm{II})$ and deoxyribonucleic acid was showed in Fig. 3. From Fig. 3, we can find that the strong interaction between chlortetracycline, $\mathrm{Ni}(\mathrm{II})$ and deoxyribonucleic acid has happened by observing the shift of absorption maximum of chlortetracycline solution. The absorption maximum of tenary complex was $410 \mathrm{~nm}$.

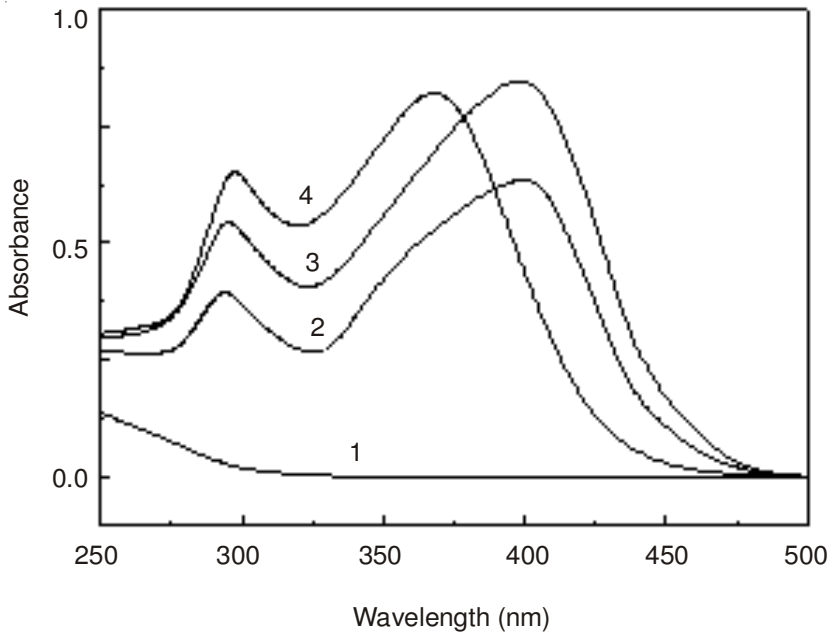

Fig. 3. Absorption spectrum, 1. Ni(II); 2. Ni-CTC-DNA; 3. Ni-CTC; 4. chlortetracycline

Effect of acidity: To investigate the effect of acidity on the formation of tenary complex and the result of phaseseparation sublation, the test conditions was in the light of procedures. Fig. 4 and 5 show that the optimal acidity of tenery complex formation and phase-separation sublation was at $\mathrm{pH}$ $10.5 \mathrm{~mL}$ of $\mathrm{Na}_{2} \mathrm{CO}_{3}-\mathrm{NaHCO}_{3}(\mathrm{pH}=10)$ buffer solution was added in the experiment.

Effect of reagents dosage and ionic strength: In order to investigate the effect of reagents dosage on the phaseseparation sublation, $5 \mathrm{~mL}$ of $1 \times 10^{-4} \mathrm{~mol} \mathrm{~L}^{-1}$ chlortetracycline was applied, the organic-phase absorbance was examined with the shift of volume of $\mathrm{Ni}$ (II) and deoxyribonucleic acid after phase-separation sublation. Fig. 6 shows the absorbance variability of binary complex of Ni-CTC with the addition of $\mathrm{Ni}(\mathrm{II})$ and tenery complex of Ni-CTC-DNA with the addition of deoxyribonucleic acid. $6 \mathrm{~mL}$ of $\mathrm{Ni}(\mathrm{II})$ and $5 \mathrm{~mL}$ of deoxyribonucleic acid were applied in the experiment. The effect of $\mathrm{NaCl}$ concentration and organic solvent was also reviewed. The results indicated that the optimal concentration of $\mathrm{NaCl}$ is $1 \mathrm{~mol} \mathrm{~L}^{-1}$ and the optimal organic solvent is THF. Moreover, the various ionic strength made no impression on floating result. 


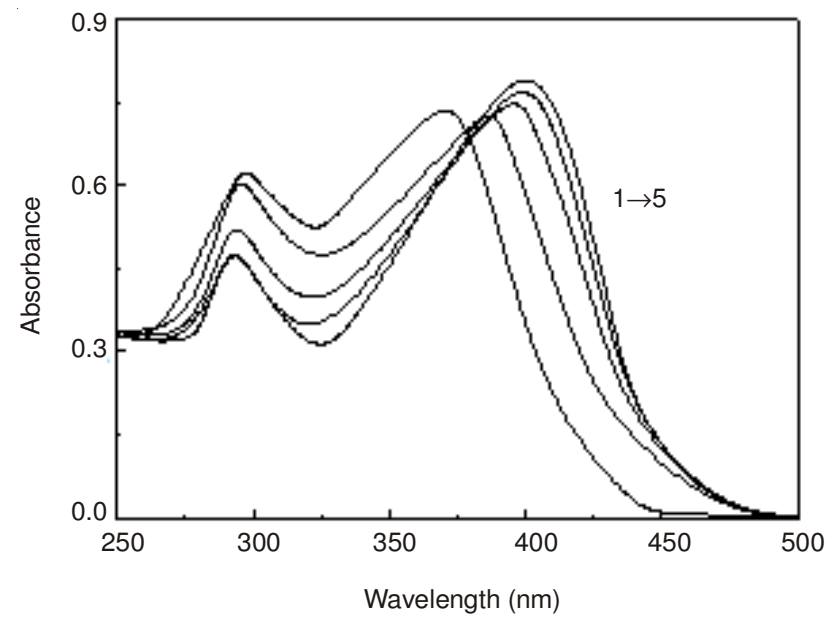

Fig. 4. Effect of acidity to absorbance of Ni-CTC-DNA, $1 \rightarrow$ 5: $\mathrm{pH}$ 6-10

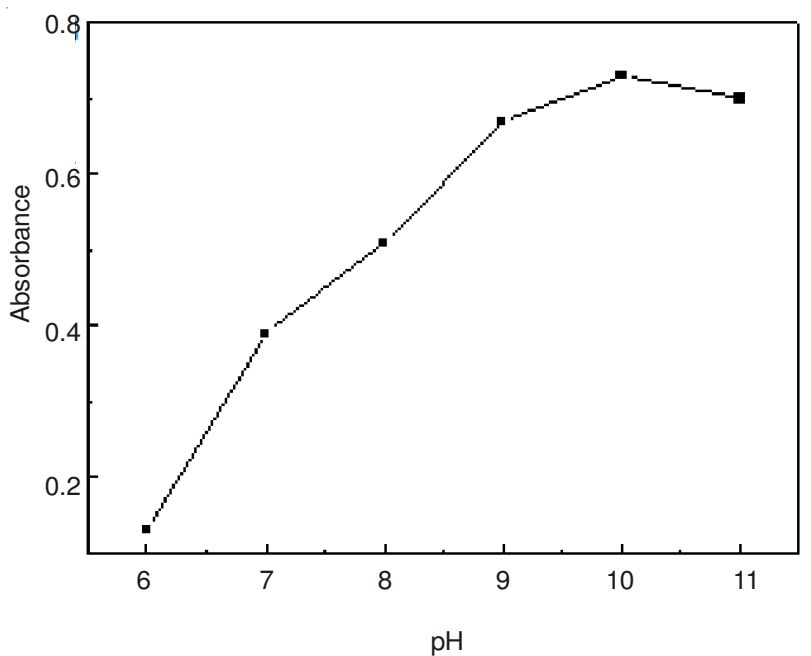

Fig . 5. Effect of acidity to organicphase absorbance

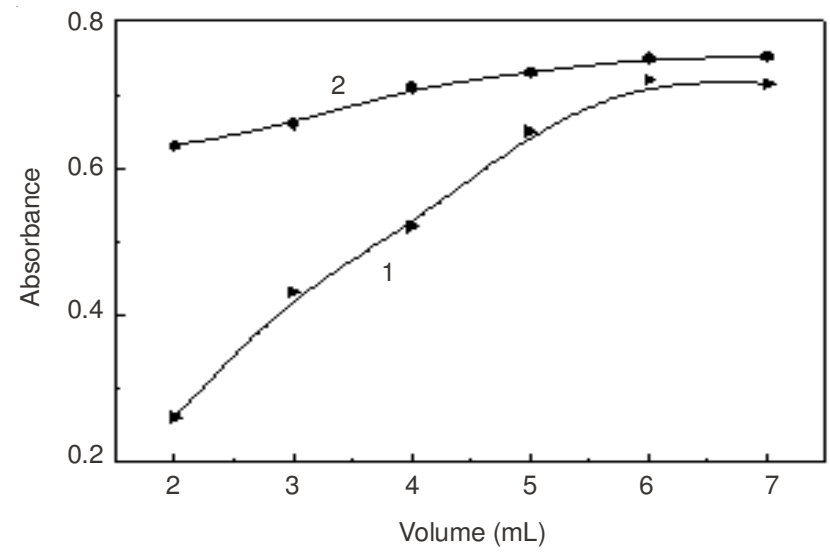

Fig. 6. Effect of added dosage change of $\mathrm{Ni}(\mathrm{II})$ and deoxyribonucleic acid to organic-phase absorbance, 1 . Ni(II); 2. deoxyribonucleic acid

Effect of reaction time, floatation time and nitrogen flow rate: Effect of floatation time and nitrogen flow rate on phase-separation sublation was investigated. The organicphase absorbance increase gradually with the extension of time for phase-separation sublation and accretion of flow rate, the particular case was showed in Fig. $7.20 \mathrm{~mL} \mathrm{~min}^{-1}$ of flow rate and $10 \mathrm{~min}$ of floatation time were chosen by integrated analysis.

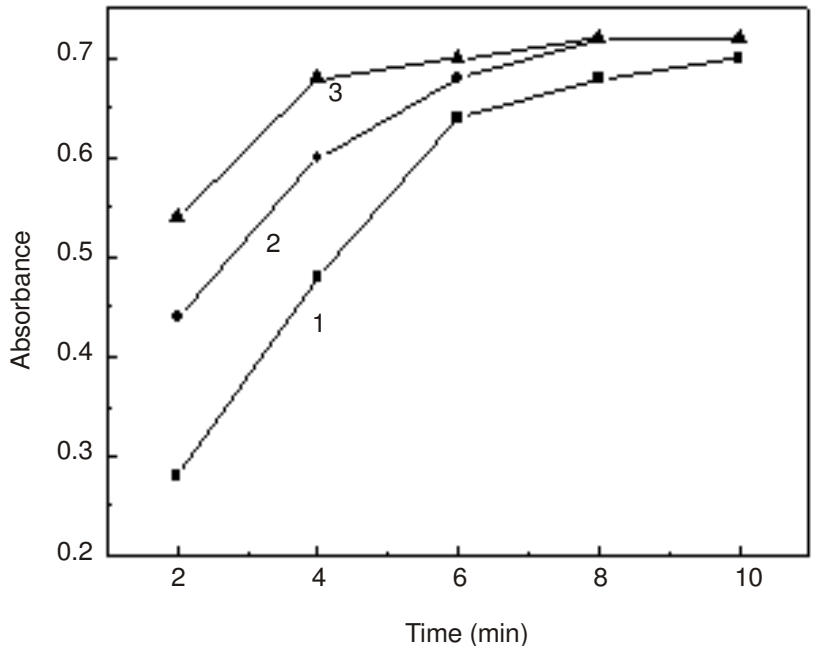

Fig. 7. Effect of floatation time and flow rate, $1.10 \mathrm{~mL} / \mathrm{min} ; 2.20 \mathrm{~mL} /$ $\mathrm{min} ; 3.30 \mathrm{~mL} / \mathrm{min}$

Reaction mechanism: Studies showed that it is coordination reaction between chlortetracycline and $\mathrm{Ni}(\mathrm{II})$, nevertheless, it is insertion process between Ni-CTC and deoxyribonucleic acid. It seems reasonable that the reaction mechanism was showed in Fig. 8.
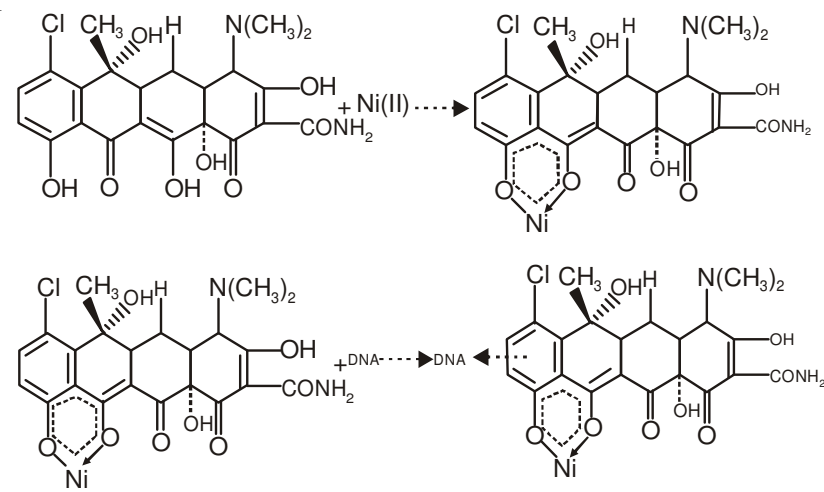

Fig. 8. Formation of Ni-CTC-DNA

Liner range and limit of detection: The detection of chlortetracycline was determined and it was $1.82 \times 10^{-9} \mathrm{~mol}$ $\mathrm{L}^{-1}$. The liner range of analytical method was calculated and it was $5.1 \times 10^{-8}-1.5 \times 10^{-5} \mathrm{~mol} \mathrm{~L}^{-1}$.

Floating rate and enrichment multiples: The experiment indicated that the floating rate was $87 \%$ and the enrichment multipules was 26.7 .

Evaluation of flotation: The standard solution of chlortetracycline and floated organic phase were used for chromatography analysis in the option conditions: Diamonsil C18 column; acetonitrile-water flowing phase and flow rate $0.8 \mathrm{~mL} \mathrm{~min}^{-1}$; VWD1A detector; wavelength $350 \mathrm{~nm}$, the results are showed in Fig. 9-12. Comparing Fig. 11 with Fig. 12, we can see that the complex of Ni-CTC-DNA $(2.5 \times$ $10^{-6} \mathrm{~mol} \mathrm{~L}^{-1}$ ) had been floated efficiently into tetrahytrofuran. Calculated with chromatography standard curve method, the floating rate was $87 \%$, this conclusion was in accordance with spctropheotometry.

Sample analysis: Take a series of different volume of urine and made it up to test solution. The content of chlortetra- 


\begin{tabular}{cccccc}
\hline \multicolumn{7}{c}{ TABLE-1 } \\
DETERMINATION RESULTS OF CTC IN URINE SAMPLES ( $=6)$ \\
\hline Sample & $\begin{array}{c}\text { Measured value } \\
\left(\times 10^{-6} \mathrm{~mol} / \mathrm{L}\right)\end{array}$ & $\begin{array}{c}\text { Spiked value } \\
\left(\times 10^{-6} \mathrm{~mol} / \mathrm{L}\right)\end{array}$ & $\begin{array}{c}\text { Measured total } \\
\left(\times 10^{-6} \mathrm{~mol} / \mathrm{L}\right)\end{array}$ & Recovery $(\%)$ & RSD $(\%)$ \\
\hline 1 & 0.08 & 0.1 & 0.107 & 99.5 & 1.3 \\
2 & 0.07 & 0.1 & 0.106 & 99.2 & 0.68 \\
3 & 0.06 & 0.1 & 0.107 & 901 & 1.01 \\
4 & 0.1 & 0.1 & 0.198 & 0.77 \\
5 & 0.2 & 0.2 & 0.398 & 99.6 & 1.2 \\
6 & 0.4 & 0.4 & 1.584 & 99.4 & 0.89 \\
7 & 0.8 & 0.8 & 2.01 & 99.1 & 1.4 \\
8 & 1.0 & 1.0 & & 100.5 & 0.94 \\
\hline
\end{tabular}

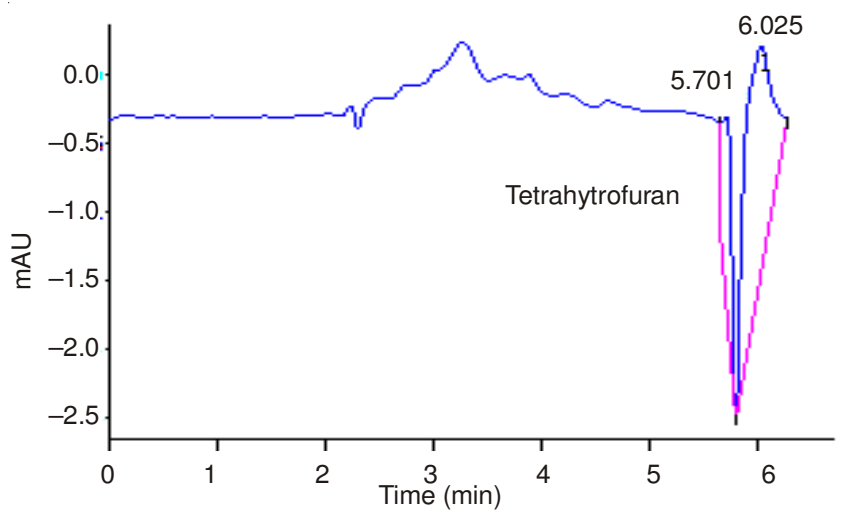

Fig. 9. Chromatogram of tetrahytrofuran

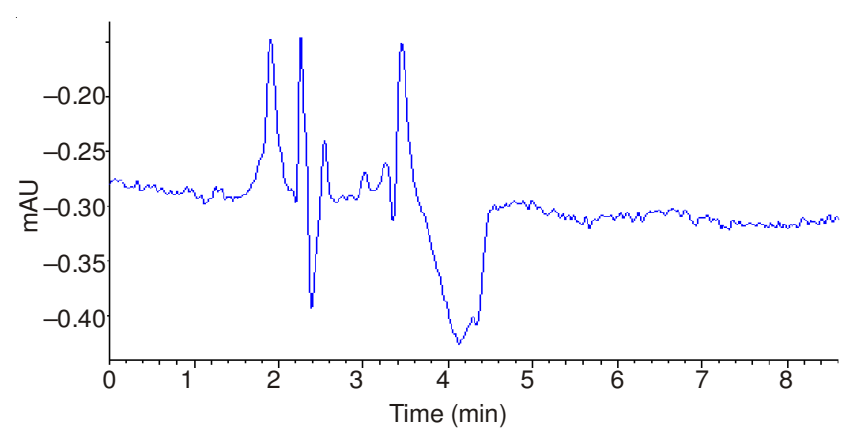

Fig. 10. Liquid chromatogram of deoxyribonucleic acid

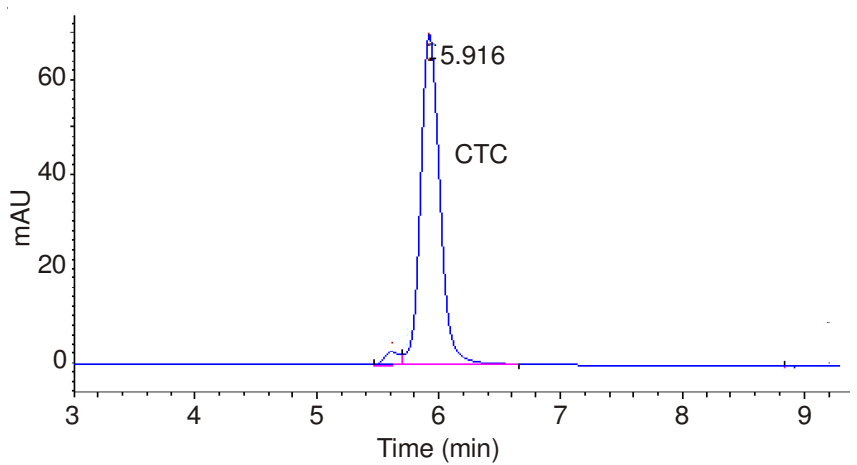

Fig. 11. Liquid chromatogram of standard solution of chlortetracycline

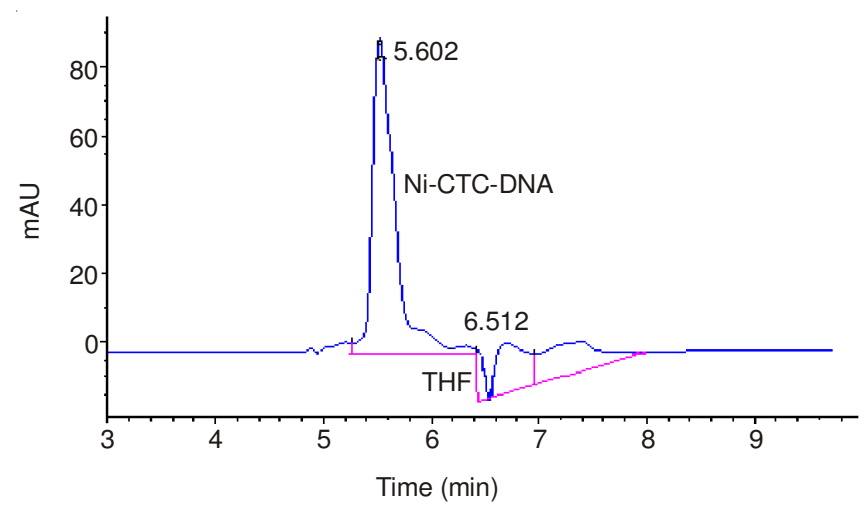

Fig. 12. Liquid chromatogram of Ni-CTC-DNA

cycline in urine was determined using the experimental procedure, the results were shown in Table-1.

\section{ACKNOWLEDGEMENTS}

This research was financially supported by Henan Provincial Natural Science Foundation of China.

\section{REFERENCES}

1. S. Sarter, H.N. Kha Nguyen, L.T. Hung, J. Lazard and D. Montet, Food Contr., 18, 1391 (2007).

2. F. Mwanuzi, H. Aalderink and L. Mdamo, Environ. Int., 29, 95 (2003).

3. S. Thiele, J. Plant Nutr. Soil Sci., 163, 589 (2000).

4. N.S. Simon, Environ. Sci. Technol., 39, 3480 (2005).

5. G. Hamscher, S. Sczesny, H. Hoper and H. Nau, Anal. Chem., 74, 1509 (2002).

6. Y. Agerso, G. Wulff, E. Vaclavik, B. Halling-Sørensen and L.B. Jensen, Environ. Int., 32, 876 (2006).

7. S.A. Sassman and L.S. Lee, Environ. Sci. Technol., 39, 7452 (2005).

8. M. Loke, S. Jespersen, R.J. Vreeken, B. Halling-Sørensen and J. Tjørnelund, J. Chromatogr. B, 783, 11 (2003).

9. R.A. Figueroa, A. Leonard and A.A. MacKay, Environ. Sci. Technol., 38, 476 (2004) 